\title{
Inside the black box: How important is the credit channel relative to the interest and exchange rate channels?
}

\author{
Iris Claus * \\ Inland Revenue, New Zealand and CAMA, Australian National University, Australia
}

\section{A R T I C L E I N F O}

Article history:

Accepted 2 October 2010

\section{JEL classification:}

E32

E44

E50

F41

Keywords:

Transmission channels

Open economy

General equilibrium model

\begin{abstract}
A B S T R A C T
This paper develops a dynamic general equilibrium model to assess the importance of the credit channel relative to the interest and exchange rate channels. It is motivated by increasing theoretical and empirical evidence that credit market conditions affect the propagation of cyclical fluctuations in the economy. The relative contribution of each channel is determined by comparing the impulse responses when the relevant channel is suppressed with the impulse responses when all three channels are operating. The analysis shows that all three channels affect business cycle dynamics. But the interest rate channel has the largest effects in the transmission of shocks to the economy. The results suggest that it is substantially more important than the credit channel.
\end{abstract}

(c) 2010 Elsevier B.V. All rights reserved.

\section{Introduction}

This paper develops a dynamic general equilibrium model to assess the importance of the credit channel relative to the interest and exchange rate channels. The credit channel, which operates in addition to the traditional interest and exchange rate channels, focuses on the role of credit markets in transmitting shocks to the economy. The paper is motivated by increasing theoretical and empirical evidence that credit market conditions can affect the propagation of cyclical fluctuations.

The idea that credit conditions can have real economic effects is not new. It has been examined since at least Wicksell's early writings on monetary dynamics (Wicksell, 1906) and Fisher's "debt-deflation theory of great depressions" (Fisher, 1933). More recently, distressed financial and banking systems, e.g. in the United States, the United Kingdom, Scandinavia, Latin America, Japan and other east Asian countries, have rekindled interest in the role of credit markets in business cycle fluctuations. For example, based on Bernanke and Gertler's (1989) seminal contribution, Carlstrom and Fuerst (1997) and Bernanke et al. (1999) develop a closed economy general equilibrium model, in which credit market frictions (in the form of endogenous agency costs) alter business cycle dynamics. In these models, endogenous agency costs arise because of asymmetric information between borrowers and lenders and costly state

* P.O. Box 2198, Wellington, New Zealand. Tel.: +64 4890 6028, fax: +64 4978 1623.

E-mail address: Iris.Claus@ird.govt.nz. verification (Townsend, 1979). When lenders delegate control over resources to borrowers, agents (borrowers) have an incentive not to perform in the best interest of principals (lenders).

The theoretical findings of credit market effects have been supported by empirical evidence. For instance, Gertler and Gilchrist (1994) show that, following economic downturns, borrowing and output by bank dependent firms often fall more than borrowing and output by firms with access to public debt markets. Gertler and Gilchrist's finding for U.S. manufacturing firms is confirmed for more than 100 countries by Braun and Larrain (2005). Another example is Mody et al. (2007), who demonstrate that regional and country specific availability of credit has a strong influence on output movements in North America and Europe.

Much of the theoretical and empirical literature to date has focused on the credit channel separately in the propagation of shocks to the economy. ${ }^{1}$ Using a dynamic general equilibrium model this paper examines the feedbacks from credit markets to the real economy relative to the conventional exchange and interest rate channels. The contribution of this paper is to incorporate all three channels in a single model and to analyse their relative importance in transmitting shocks to the economy.

The framework of analysis is a small open economy that operates under a flexible exchange rate with imperfect competition and sticky prices. The model is calibrated for New Zealand. The choice of calibration is led by the structure of the New Zealand economy. New

\footnotetext{
${ }^{1}$ An exception is Tang (2006), who analyses the relative importance of monetary policy channels in Malaysia in a structural vector autoregression (SVAR) framework.
} 
Zealand, a small open economy, is one of the least regulated economies in the Organisation for Economic Co-operation and Development (OECD) and without regular foreign exchange market interventions.

The paper proceeds as follows. Section 2 describes the theoretical model. Section 3 discusses the adjustment of the economy to shocks. The relative importance of the transmission channels is evaluated in Section 4. The last section summarises and concludes.

\section{Theoretical model}

This section develops the theoretical model that is used to assess the relative importance of the interest and exchange rate and credit channels. There are six agents in the model: financial intermediaries, households, entrepreneurs, firms, a government and an inflation targeting monetary authority.

The credit channel arises because of asymmetric information between borrowers and lenders. Entrepreneurs (borrowers) must obtain external financing from households via financial intermediaries (lenders) to produce capital goods. This leads to agency costs because entrepreneurs' production is subject to idiosyncratic technology shocks that only entrepreneurs can costlessly observe. To obtain external financing, entrepreneurs must have collateral (net worth). The credit channel arises from the impact of economic shocks on entrepreneurs' net worth and their ability to borrow.

The interest rate channel results from the central bank's response to economic shocks. To maintain its consumer price inflation target, following a shock to the economy the central bank adjusts the rate of interest rate paid on domestic bonds. A change in the interest rate is transmitted to the real economy through its impact on the cost of consumption and the rate of return to capital. A change in the interest rate also affects the exchange rate.

The exchange rate channel mainly operates through net exports. Real exchange rate changes affect the cost of commodity imports, which are an input in firms' production of consumption goods. They also impact on the price of exports and the foreign demand for firms' output. Moreover, exchange rate movements influence full capacity output.

The theoretical model that incorporates the interest and exchange rate and credit channels is developed next.

\subsection{Financial intermediaries}

The credit channel results because entrepreneurs must obtain external financing from households via financial intermediaries. As in Carlstrom and Fuerst (1997) entrepreneurs produce capital (investment) goods, which firms use as an input in the production of consumption goods. Each entrepreneur $i$ borrows $\left(\operatorname{IN}_{t}(i)-N W_{t}(i)\right)$ consumption goods, where $I N_{t}(i)$ is the size of entrepreneur $i$ 's investment good production and $N W_{t}(i)$ is entrepreneur $i$ 's net worth or internal funds. After capital is produced loans are repaid in capital goods.

Each entrepreneur $i$ has access to a stochastic technology, $\omega_{t}(i)$, that transforms an input of $I N_{t}$ consumption goods into $\omega_{t}(i) I N_{t}$ units of new capital. The distribution function and density of $\omega_{t}(i)$ are given by $\Phi\left(\omega_{t}(i)\right)$ and $\phi\left(\omega_{t}(i)\right)^{2}$ Entrepreneurs (borrowers) can costlessly observe the stochastic technology. Lenders can only reveal it at a monitoring cost of $\alpha I N_{t}(i)$, where $\alpha \in[0,1]$ is a parameter. The information asymmetry creates a moral hazard problem because entrepreneurs have an incentive to underreport their true value of $\omega_{t}(i)$. Financial intermediaries can reduce the information asymmetry by structuring a financial contract so that entrepreneur $i$ always

\footnotetext{
2 The random variable $\omega_{t}(i) \in[0,1]$ is assumed to be lognormally distributed across time and entrepreneurs, i.e. $\ln \left(\omega_{t}(i)\right) \sim N\left(\tilde{\mu}, \tilde{\sigma}^{2}\right)$, with a mean of unity and a standard deviation of $\sigma$.
}

truthfully reports the value of $\omega_{t}(i)$. The optimal contract is characterised by the size of entrepreneur $i$ 's production, $I N_{t}(i)$, and a critical value for $\omega_{t}(i)$ that triggers bankruptcy, denoted by $\varpi_{t}(i)$. If the realisation of $\omega_{t}(i)$ is below the critical $\varpi_{t}(i)$, the entrepreneur becomes bankrupt and defaults on the debt contract. In the event of default, the financial intermediary monitors the entrepreneur, as in Williamson (1986), confiscates all returns from the project and absorbs any losses.

To derive the optimal project size $I N_{t}(i)$ and the critical $\varpi_{t}(i)$ that triggers bankruptcy two functions, $f(\varpi)$ and $g(\varpi)$, are defined. They are the fractions of the expected net capital output received by the entrepreneur and the lender. Time and entrepreneur subscripts have been dropped for simplicity. The functions are given by $f(\varpi)=$ $\int_{\varpi}^{\infty}(\omega-\varpi) d \Phi(\omega)=\int_{\varpi}^{\infty} \omega d \Phi(\omega)-[1-\Phi(\varpi)] \varpi$ and $g(\varpi)=\int_{0}^{\varpi} \omega d \Phi(\omega)-$ $\alpha \Phi(\varpi)+[1-\Phi(\varpi)] \varpi . f(\varpi)$ and $g(\varpi)$ do not sum to one because of expected bankruptcy and monitoring costs, i.e. $f(\varpi)+g(\varpi)=1-$ $\alpha \Phi(\varpi)$. The expected net capital output received by the entrepreneur and the lender from entrepreneur $i$ 's production is given by $f\left(\varpi_{t}(i)\right) \hat{\Psi}_{t} I N_{t}(i)$ and $g\left(\varpi_{t}(i)\right) \hat{\Psi}_{t} I N_{t}(i)$, where $\hat{\Psi}_{t}$ is the aggregate real price of capital in terms of consumption goods. The optimal contract between the entrepreneur and the lender is given by the pair $\left(\operatorname{IN}_{t}(i)\right.$, $\left.\varpi_{t}(i)\right)$ that maximises the entrepreneur's net capital output subject to the lender being indifferent between loaning the funds to the entrepreneur and retaining them, i.e.

$\max f\left(\varpi_{t}(i)\right) \hat{\Psi}_{t} I N_{t}(i)$

subject to

$g\left(\varpi_{t}(i)\right) \hat{\Psi}_{t} I N_{t}(i) \geq I N_{t}(i)-N W_{t}(i)$

which holds as an equality at an optimum. The first-order conditions of the optimisation problem are given by

$\hat{\Psi}_{t}\left(1-\alpha \Phi\left(\varpi_{t}(i)\right)+\frac{\alpha \phi\left(\varpi_{t}(i)\right) f\left(\varpi_{t}(i)\right)}{f^{\prime}\left(\varpi_{t}(i)\right)}\right)=1$

and

$I N_{t}(i)=\frac{N W_{t}(i)}{1-g\left(\varpi_{t}(i)\right) \hat{\Psi}_{t}}$

Eq. (3) determines the critical $\varpi_{t}(i)$ as a function of the aggregate real price of capital, $\hat{\Psi}_{t}$, the distribution of the stochastic technology, $\omega_{t}(i)$, and the monitoring cost, $\alpha$. The critical $\varpi_{t}(i)$ is independent of $i$; that is, all entrepreneurs receive the same basic terms on their financial contract. Contracts only differ in terms of size - entrepreneurs with larger net worth receive a proportionately larger loan (Eq. (4)). ${ }^{3}$ Variables specific to $i$ can henceforth be interpreted as averages.

\subsection{Households}

Households are infinitely lived and a typical household values streams of consumption and leisure according to

$E_{t} \sum_{k=0}^{\infty} \beta^{k}\left\{\ln \left(C_{t+k}^{h}\right)+\gamma\left(1-N_{t+k}\right)\right\}$

where $\gamma>0$ is a parameter, $\beta \in(0,1)$ is the household's discount factor and $E_{t}$ is a conditional expectations operator with respect to information available at time $t$. Households' time endowment is

\footnotetext{
${ }^{3}$ This result overcomes the heterogeneity problem with entrepreneurs that arises from the idiosyncratic technology. It follows from the assumption of linear monitoring costs and investment technology.
} 
normalised to one. Their labour supply is given by $N_{t}$ and $\left(1-N_{t}\right)$ is leisure. Each household consumes many goods, all of which are domestically produced. $C_{t}^{h}$ is the quantity consumed in period $t$ of an index of these goods with $C_{t}^{h}=\left[\int_{0}^{1} C_{t}^{h}(j)^{(\theta-1) / \theta} d j\right]^{\theta /(\theta-1)}$, where $C_{t}^{h}(j)$ denotes the household's period $t$ consumption of good $j$ and $\theta>0{ }^{4}$

Households earn nominal income from supplying labour, $N_{t}$, at wage rate $W_{t}^{h}$ and by renting physical capital, $K_{t-1}^{h}$, accumulated last period, to firms at rate $R_{t}$. Households receive dividend payments, $\Omega_{t}$, from firms and also earn income from holding domestic bonds issued by the government, $B_{t-1}^{h}$, and foreign bonds, $B_{t-1}^{h *}$. Domestic bonds, $B_{t-1}^{h}$, earn a nominal return (in terms of domestic currency) of $I_{t}$ and the nominal rate of interest paid on foreign bonds, $B_{t-1}^{h *}$, is given by $I_{t}^{*}$. In addition, households hold demand deposits, $D_{t-1}$, to purchase consumption and capital goods. Demand deposits do not earn any interest. Households pay taxes on their wage and rental incomes. For simplicity, households' interest and dividend incomes and capital gains from exchange rate and capital price movements are not taxed. The tax rate imposed by the government is given by $\tau$. The typical household's budget constraint is thus given by

$$
\begin{aligned}
& (1-\tau) W_{t}^{h} N_{t}+\left((1-\delta) \Psi_{t}+(1-\tau) R_{t}\right) K_{t-1}^{h}+\left(1+I_{t}\right) B_{t-1}^{h} \\
& \quad+\left(1+I_{t}^{*}\right) S_{t} B_{t-1}^{h *}+\Omega_{t}+D_{t-1}-P_{t} C_{t}^{h}-B_{t}^{h}-S_{t} B_{t}^{h *}-D_{t}-\Psi_{t} K_{t}^{h}=0
\end{aligned}
$$

where $S_{t}$ denotes the nominal exchange rate, $\Psi_{t}$ is the nominal price of capital and $\delta \in(0,1)$ is the depreciation rate of capital.

The household's deposit-in-advance constraint is given by

$P_{t} C_{t}^{h}+\Psi_{t} K_{t}^{h}-(1-\delta) \Psi_{t} K_{t-1}^{h} \leq D_{t-1}$

and holds as an equality at an optimum if $I_{t}>0$. The household's budget constraint can then be re-written in real terms as

$$
\begin{aligned}
& (1-\tau) \hat{W}_{t}^{h} N_{t}+(1-\tau) \hat{R}_{t} K_{t-1}^{h}+\frac{\left(1+I_{t}\right) \hat{B}_{t-1}^{h}}{1+\Pi_{t}}+\frac{\left(1+I_{t}^{*}\right) Q_{t} \hat{B}_{t-1}^{h *}}{1+\Pi_{t}^{*}} \\
& \quad+\hat{\Omega}_{t}-\hat{B}_{t}^{h}-Q_{t} \hat{B}_{t}^{h *}-\left(1+\Pi_{t+1}\right)\left(C_{t+1}^{h}+\hat{\Psi}_{t+1} K_{t+1}^{h}-(1-\delta) \hat{\Psi}_{t+1} K_{t}^{h}\right)=0
\end{aligned}
$$

The real wage and rental rates are given by $\hat{W}_{t}^{h}$ and $\hat{R}_{t}$, and $\hat{B}_{t}^{h}, \hat{B}_{t}^{h *}$ and $\hat{\Omega}_{t}$ are the household's domestic and foreign bond holdings and dividend payments in real terms. $Q_{t}$ denotes the real exchange rate, $Q_{t} \equiv S_{t} P_{t}^{*} / P_{t} . \Pi_{t}$ is the domestic inflation rate with $\Pi_{t}=P_{t} / P_{t-1}-1$ and the foreign inflation rate is given by $\Pi_{t}^{*}=P_{t}^{*} / P_{t-1}^{*}-1$, where $P_{t}^{*}$ is the aggregate foreign price level.

The household's optimisation problem consists of choosing $\left\{C_{t}^{h}, N_{t}, K_{t}^{h}, \hat{B}_{t}^{h}, \hat{B}_{t}^{h *}\right\}$ for all $t \in[0, \infty)$ to maximise lifetime utility (Eq. (5)) subject to Eq. (8). Dividends are paid at the end of each period and do not affect households' optimisation problem. Households' first-order conditions are given by

$$
\begin{aligned}
& \frac{1}{\gamma C_{t}^{h}}-\frac{\left(1+I_{t}\right)}{(1-\tau) \hat{W}_{t}^{h}}=0 \\
& \frac{\hat{\Psi}_{t}}{C_{t}^{h}}-E_{t}\left[\frac{\beta\left((1-\delta) \hat{\Psi}_{t+1}+\frac{(1-\tau) \hat{R}_{t+1}}{1+I_{t+1}}\right)}{C_{t+1}^{h}}\right]=0
\end{aligned}
$$

\footnotetext{
${ }^{4}$ Entrepreneurs' and the government's consumption indexes are given accordingly.
}

and

$E_{t}\left[\frac{Q_{t+1}}{Q_{t}} \frac{1+I_{t+1}^{*}}{1+\Pi_{t+1}^{*}}-\frac{1+I_{t+1}}{1+\Pi_{t+1}}\right]=0$

At an optimum the marginal rate of substitution between consumption and leisure is equal to the relative price of consumption, i.e. the ratio of the effective price of consumption and the after-tax real wage rate. The effective price of consumption is the sum of its market price (equal to unity) and the opportunity cost of having to hold demand deposits to purchase consumption goods, $I_{t}$. Further, the marginal rate of substitution between consumption today and next period is equal to the effective return from accumulating an additional unit of capital. The effective return is given by a unit value of the capital stock net of depreciation plus the after-tax rate of return on capital adjusted for the opportunity cost of having to hold demand deposits to purchase capital. Finally, real rates of return of domestic and foreign bonds are equal and households are indifferent between holding domestic or foreign bonds.

Eqs. (9)-(11) show how the interest rate channel operates through the household sector. A change in interest rates affects households' opportunity cost of consumption and the rental rate of capital. These effects arise because of the deposit-in-advance constraint. Moreover, a change in interest rates impacts on the exchange rate.

\subsection{Entrepreneurs}

Entrepreneurs are infinitely lived. The typical entrepreneur's utility function is given by

$E_{t} \sum_{k=0}^{\infty}(\vartheta \beta)^{k} C_{t+k}^{e}$

where $C_{t}^{e}$ is an index of entrepreneurial consumption in period $t$ and $\vartheta \in(0,1)$ is an additional discount factor. Entrepreneurs are assumed to discount the future more heavily than households. This ensures that entrepreneurs obtain external financing from households to produce capital goods. Agency costs imply that the return to internal funds is greater than the return to external funds and entrepreneurs have an incentive to postpone all consumption and accumulate internal funds to self-finance. With no external financing, the credit channel disappears.

The typical entrepreneur's budget constraint is given by

$$
\left((1-\tau) \hat{W}_{t}^{e}+\left((1-\delta) \hat{\Psi}_{t}+(1-\tau) \hat{R}_{t}\right) K_{t-1}^{e}\right) \frac{f\left(\varpi_{t}\right) \hat{\Psi}_{t}}{1-g\left(\varpi_{t}\right) \hat{\Psi}_{t}}-C_{t}^{e}-\hat{\Psi}_{t} K_{t}^{e}=0
$$

where $(1-\tau) \hat{W}_{t}^{e}+\left((1-\delta) \hat{\Psi}_{t}+(1-\tau) \hat{R}_{t}\right) K_{t-1}^{e}$ denotes the entrepreneur's net worth (internal funds) to produce capital goods, entrepreneurial labour supply is equal to unity and $K_{t-1}^{e}$ is the entrepreneur's capital stock from the previous period. Entrepreneurs' net worth earns a gross expected return to internal funds of $\left(1+I R_{t}\right)=f\left(\varpi_{t}\right) \hat{\Psi}_{t} /\left(1-g\left(\varpi_{t}\right) \hat{\Psi}_{t}\right)$, where $f\left(\varpi_{t}\right) \hat{\Psi}_{t}$ is the expected share of net capital output received by the entrepreneur and $g\left(\varpi_{t}\right) \hat{\Psi}_{t}$ is the expected share received by the lender. As in the case of households, entrepreneurs' wage earnings and return to capital are taxed but capital gains from capital price movements are not. The entrepreneur uses the proceeds from the production of capital to purchase consumption goods, $C_{t}^{e}$. $K_{t}^{e}$ denotes the entrepreneurial capital left after consumption. 
The entrepreneur's optimisation problem consists of choosing $\left\{C_{t}^{e}, K_{t}^{e}\right\}$ for all $t \in[0, \infty)$ to maximise lifetime utility (Eq. (12)) subject to Eq. (13). The entrepreneur's first-order condition is given by

$\hat{\Psi}_{t}=E_{t}\left[\frac{\vartheta \beta\left((1-\delta) \hat{\Psi}_{t+1}+(1-\tau) \hat{R}_{t+1}\right) f\left(\varpi_{t+1}\right) \hat{\Psi}_{t+1}}{1-g\left(\varpi_{t+1}\right) \hat{\Psi}_{t+1}}\right]$

where the gross expected return on internal funds, $f\left(\varpi_{t+1}\right) \hat{\Psi}_{t+1} /$ $\left(1-g\left(\varpi_{t+1}\right) \hat{\Psi}_{t+1}\right)$, is greater than one. ${ }^{5}$ This additional return encourages entrepreneurs to accumulate capital even though they discount the future more than households.

\subsection{Firms}

Firms are monopolistic competitors and specialise in production. A typical firm produces output of consumption good $j, Y_{t}(j)$, under a constant elasticity of substitution (CES) technology by hiring household and entrepreneurial labour, $L_{t}^{h}(j)$ and $L_{t}^{e}(j)$, using capital, $K_{t-1}(j)$, and commodity inputs, $\operatorname{IM}_{t}(j)$. Production inputs are purchased in competitive factor markets. Firms rent the capital from households and entrepreneurs, and import the commodity inputs at the beginning of each period. Firm $j$ 's production function is given by

$$
\begin{aligned}
Y_{t}(j)= & {\left[\left(\eta_{l}\left(Z_{t} L_{t}^{h}(j)\right)^{v}+\eta_{k}\left(K_{t-1}(j)\right)^{v}+\eta_{i m}\left(I M_{t}(j)\right)^{v}\right.\right.} \\
& \left.+\left(1-\eta_{l}-\eta_{k}-\eta_{i m}\right)\left(L_{t}^{e}(j)\right)^{v}\right]^{\frac{1}{v}}
\end{aligned}
$$

where $\eta_{l}, \eta_{k}, \eta_{i m} \in(0,1]$ are parameters and $\nu<1$; that is, the marginal return to each input is diminishing. $Z_{t}$ denotes productivity and the elasticity of substitution in production is given by $1 /(1-\nu)$.

The assumption of monopolistic competition in the consumption goods market allows pricing decisions to be determined explicitly. A firm treats the price in domestic currency, $P_{t}(j)$, of the consumption good $j$ it produces as a choice variable, while taking the domestic aggregate price level, $P_{t}$, the nominal exchange rate, $S_{t}$, and the foreign price level, $P_{t}^{*}$, as given. Having chosen $P_{t}(j)$, the firm then produces the quantity of output demanded at that price. ${ }^{6}$ Each firm sells its output of consumption good, $Y_{t}(j)$, to domestic households, $C_{t}^{h}(j)$, entrepreneurs, $C_{t}^{e}(j)$, and the government, $G_{t}(j)$. Firms also export to the rest of the world, $E X_{t}(j)$. The demand functions for good $j$ are given by $C_{t}^{h}(j)=\left(P_{t}(j) / P_{t}\right)^{-\theta} C_{t}^{h}, C_{t}^{e}(j)=\left(P_{t}(j) / P_{t}\right)^{-\theta} C_{t}^{e}$ and $G_{t}(j)=\left(P_{t}(j) /\right.$ $\left.P_{t}\right)^{-\theta} G_{t}$, where $C_{t}^{h}, C_{t}^{e}$ and $G_{t}$ are total consumption by the typical household and entrepreneur and the government. ${ }^{7}$ Similarly, foreign demand for consumption good $j$ is given by $E X_{t}(j)=\left(P_{t}(j) / P_{t}\right)^{-\theta} E X_{t}$, where $E X_{t}$ denotes aggregate exports. $E X_{t}$ is a function of the real exchange rate, $Q_{t}$, and foreign demand for the domestic country's output, $Y_{t}^{*}$, and given by

$E X_{t}=\left(Q_{t}\right)^{\kappa}\left(Y_{t}^{*}\right)^{\varsigma}$

where $\kappa, \varsigma>0$ are the price and foreign demand elasticities of exports. ${ }^{8}$

In a symmetric equilibrium, all firms charge the same price, produce the same output, employ the same labour and capital and use

\footnotetext{
${ }^{5}$ Eq. (14) is derived from the entrepreneur's optimisation with respect to $C_{t}^{e}$, which leads to $1-\lambda_{t}=0$, and $K_{t}^{e}$, which results in $-\lambda_{t} \hat{\Psi}_{t}+E_{t}\left[\left(\lambda_{t+1} \vartheta \beta\left((1-\delta) \hat{\Psi}_{t+1}+\right.\right.\right.$ $\left.\left.\left.(1-\tau) \hat{R}_{t+1}\right) f\left(\varpi_{t+1}\right) \hat{\Psi}_{t+1}\right) /\left(1-g\left(\varpi_{t+1}\right) \hat{\Psi}_{t+1}\right)\right]=0$, where $\lambda_{t}$ denotes the Lagrange multiplier. In the calibration, $\vartheta$ is set to offset the steady state internal return, i.e. $\vartheta f(\bar{\varpi}) \bar{\Psi} /(1-g(\bar{\varpi}) \bar{\Psi})=1$, to avoid self-financing. Letters with a “-” indicate (average) steady state levels.

${ }^{6}$ Firms may not price discriminate and the price of good $j$ sold to foreign consumers (denominated in foreign currency) is given by $P_{t}(j) / S_{t}$.

${ }^{7}$ The aggregate price level, $P_{t}$, is an index given by $P_{t}=\left[\int_{0}^{1} P_{t}(j)^{1-\theta} d j\right]^{1 /(1-\theta)}$, where $\theta$ is the price elasticity of demand faced by each monopolistic competitive firm.

${ }^{8}$ The domestic economy's exports are assumed to form an insignificant proportion of foreigners' demand and have a negligible weight in the rest of the world's price index, that is the small economy assumption.
}

the same commodity inputs. They choose $\left\{L_{t}^{h}, L_{t}^{e}, I M_{t}, K_{t-1}\right\}$ to maximise profits subject to their production and demand functions. Firms' first-order conditions are given by

$\hat{W}_{t}^{h}=\frac{\eta_{l}\left(Z_{t}\right)^{v}\left(\frac{Y_{t}}{L_{t}^{h}}\right)^{1-v}}{\frac{\theta}{\theta-1}}$

$\hat{W}_{t}^{e}=\frac{\left(1-\eta_{l}-\eta_{k}-\eta_{i m}\right)\left(\frac{Y_{t}}{L_{t}^{e}}\right)^{1-v}}{\frac{\theta}{\theta-1}}$

$\hat{R}_{t}=\frac{\eta_{k}\left(\frac{Y_{t}}{K_{t-1}}\right)^{1-v}}{\frac{\theta}{\theta-1}}$

and

$Q_{t}=\frac{\eta_{i m}\left(\frac{Y_{t}}{I M_{t}}\right)^{1-v}}{\frac{\theta}{\theta-1}}$

They show that firms sell their output of consumption goods at a mark-up over production costs and factor prices are below their marginal products. Under price flexibility the mark-up is constant and equal to $\theta /(\theta-1)$. Under price stickiness it is given by $\xi_{t}$. The mark-up gives rise to economic profits of $\left(\xi_{t}-1\right) Y_{t} / \xi_{t}$, which are paid to households as dividends, $\hat{\Omega}_{t}$, at the end of each period.

The exchange rate channel operates through firms' net exports. Real exchange rate movements influence the supply and demand of final products and factors of production. A change in the exchange rate affects the cost of production through its impact on the price of imported inputs. It also affects the price of exports and the foreign demand for firms' output.

\subsection{Government}

The government collects taxes on households' and entrepreneurs' wage and rental incomes, $\tau\left(\hat{W}_{t}^{h} L_{t}^{h}+\hat{W}_{t}^{e} L_{t}^{e}+\hat{R}_{t}\left(K_{t-1}^{h}+K_{t-1}^{e}\right)\right)$. It uses this revenue to purchase an index of consumption goods, $G_{t}$, from firms. For simplicity, the government's budget constraint is assumed to balance in each period, i.e. there is no debt financing ${ }^{9}$

$\tau\left(\hat{W}_{t}^{h} L_{t}^{h}+\hat{W}_{t}^{e} L_{t}^{e}+\hat{R}_{t}\left(K_{t-1}^{h}+K_{t-1}^{e}\right)\right)-G_{t}=0$

\subsection{Monetary authority}

The monetary authority has an explicit consumer price inflation target, $\Pi^{T}$. To maintain this target following a shock to the economy the central bank adjusts the nominal rate of interest paid on domestic bonds. The central bank's reaction function is discussed further in the next section.

\subsection{Equilibrium conditions}

The clearing conditions are given by

$L_{t}^{h}=(1-\eta) N_{t}$

\footnotetext{
${ }^{9}$ No debt financing implies that $\hat{B}_{t}^{h}=0$ for all $t$.
} 
$L_{t}^{e}=\eta$

$Y_{t}=(1-\eta) C_{t}^{h}+\eta C_{t}^{e}+G_{t}+E X_{t}+\eta I N_{t}$

$K_{t}=K_{t}^{h}+K_{t}^{e}$

and

$K_{t}=(1-\delta) K_{t-1}+\eta I N_{t}\left(1-\alpha \Phi\left(\varpi_{t}\right)\right)$

where $(1-\eta)$ is the proportion of households and $\eta$ is the proportion of entrepreneurs. ${ }^{10}$ Moreover, entrepreneurial labour supply is equal to unity.

The current account balance is given by

$C A_{t}=E X_{t}-Q_{t} I M_{t}$

Uncovered interest rate parity holds

$1+I_{t}=E_{t}\left[\left(1+I_{t}^{*}\right) \frac{S_{t+1}}{S_{t}}\right]$

and implies that households are indifferent between holding domestic or foreign bonds. Households' foreign bond holdings are determined at the end of each period from the foreign sector clearing condition. They do not affect households' decisions and are hence disregarded.

The real exchange rate, $Q_{t}$, evolves according to

$E_{t}\left[\frac{Q_{t+1}}{Q_{t}}\right]=E_{t}\left[\frac{\frac{S_{t+1}}{S_{t}} \frac{P_{t+1}^{*}}{P_{t}^{*}}}{\frac{P_{t+1}}{P_{t}}}\right]$

and the sequences of the foreign interest rate, prices, inflation and foreign demand $\left\{I_{t}^{*}, P_{t}^{*}, \Pi_{t}^{*}, Y_{t}^{*}\right\}$ are given to the small open economy.

\subsection{Parameterisation and steady state of the model}

A period in the model corresponds to one quarter. Parameter values are chosen so that the steady state of the model is broadly consistent with New Zealand data and/or assumptions made in the literature. Appendix A contains the details of the parameterisation and the equations solving for the steady state of the model are given in Appendix B.

\section{Adjustment of the economy to shocks}

To evaluate the relative importance of the interest and exchange rate and credit channels, the economy is subjected to a range of exogenous shocks. The dynamic responses are derived in terms of logarithmic deviations from steady state (denoted by lower case letters). The relative contribution of each transmission channel is determined by comparing the impulse responses when the relevant channel is shutdown with the impulse responses when all three channels are operating. ${ }^{11}$ This approach is borrowed from the empirical vector autoregression literature. ${ }^{12}$

\footnotetext{
10 The number of firms is equal to the number of entrepreneurs.

11 The channels are shutdown by setting the relevant variables and logarithmic deviations from steady state to zero.

12 See, for example, Ramey (1993), Dungey and Pagan (2000) and Ludvigson et al. (2002)
}

Analysing the dynamic responses requires specifying firms' price adjustment, full capacity, flexible price output and the central bank's reaction function.

\subsection{Firms' price adjustment}

Firms' price adjustment follows Calvo (1983) and is assumed to be sluggish. Each period there is a constant probability, $\varphi$, that firms can adjust their prices. This leads to the following inflation equation

$\pi_{t}=\beta E_{t}\left[\pi_{t+1}\right]+\mathrm{Q}\left(y_{t}-\widetilde{y}_{t}\right)$

where $\varrho=\varphi(1-(1-\varphi) \beta) /(1-\varphi) \theta$ and $\widetilde{y}_{t}$ is the log level of aggregate flexible price output of consumption goods. ${ }^{13}$ Eq. (30) states that inflation is a function of expected future inflation and deviations of output from full capacity, flexible price output, i.e. the output gap. In the dynamic analysis the probability that firms can adjust prices is set to 0.33 , i.e. prices remain unchanged on average for three quarters.

\subsection{Full capacity, flexible price output}

Full capacity, flexible price output, $\tilde{y}_{t}$, is the total domestic output of consumption goods that would be produced under price flexibility. In that case firms' mark-up is constant and output is given by

$\tilde{y}_{t}=\eta_{l}\left(\frac{\bar{Z} \bar{L}^{h}}{\bar{Y}}\right)^{v} z_{t}+\eta_{l}\left(\frac{\bar{Z} \bar{L}^{h}}{\bar{Y}}\right)^{v} \tilde{l}_{t}^{h}+\eta_{k}\left(\frac{\bar{K}}{\bar{Y}}\right)^{v} \tilde{k}_{t-1}+\eta_{i m}\left(\frac{I \bar{M}}{\bar{Y}}\right)^{v} i \tilde{m}_{t}$

where $\tilde{l}_{t}^{h}, \tilde{k}_{t-1}$ and $i \tilde{m}_{t}$ denote flexible price household labour, capital and commodity imports. ${ }^{14}$ Flexible price household labour, $\tilde{l}_{t}^{h}$, can be derived from households' first-order condition that the marginal utility of leisure is equal to the after-tax real wage rate and firms' first-order condition determining labour demand (Eq. (17)). It is given by $\tilde{l}_{t}^{h}=\tilde{y}_{t}+(v /(1-v)) z_{t}$. Flexible price capital, $\tilde{k}_{t-1}$, and commodity imports, $i \tilde{m}_{t}$, are derived from firms' first-order conditions (19) and (20) and given by $\tilde{k}_{t-1}=\tilde{y}_{t}-(1 /(1-v)) r_{t}$ and $i \tilde{m}_{t}=\tilde{y}_{t}-(1 /(1-v)) q_{t}$. Eq. (31) can then be re-written as

$\tilde{y}_{t}=\frac{1}{1-v} z_{t}-\frac{\eta_{k}\left(\frac{\bar{K}}{\bar{Y}}\right)^{v}}{\eta_{l}(1-v)\left(\frac{\bar{Z} \bar{L}^{h}}{\bar{Y}}\right)^{v}} r_{t}-\frac{\eta_{i m}\left(\frac{I \bar{M}}{\bar{Y}}\right)^{v}}{\eta_{l}(1-v)\left(\frac{\bar{Z} \bar{L}^{h}}{\bar{Y}}\right)^{v}} q_{t}$

Full capacity, flexible price output is a function of labour augmenting productivity, the rental rate of capital and the real exchange rate. Eq. (32) shows that in addition to net exports the exchange rate channel also operates through full capacity, flexible price output.

\subsection{Monetary authority's reaction function}

The monetary authority's reaction function is given by

$i_{t}=\mu_{1} \pi_{t}+\mu_{2}\left(y_{t}-\tilde{y}_{t}\right)+\mu_{3} i_{t-1}$

The coefficients on inflation, the output gap and the past interest rate are given by $\mu_{1}=1.5, \mu_{2}=0.5$ and $\mu_{3}=0.8$. The choice for $\mu_{1}$ and $\mu_{2}$ is based on the parameter values in a Taylor rule (Taylor, 1993). ${ }^{15}$ The coefficient on the lagged interest rate, $\mu_{3}$, is the same as in

\footnotetext{
13 Firms' discount factor, $\beta$, is assumed to be the same as for households.

${ }^{14}$ Entrepreneurial labour input is equal to $\eta$ for all $t$ and drops out.

15 The original Taylor rule does not include the lagged interest rate.
} 
McCallum and Nelson (1999) and in line with estimates for New Zealand by Huang et al. (2001), who find strong evidence of interest rate smoothing.

\section{Business cycle effects}

To illustrate the effects of the interest and exchange rate and credit channels, two shocks are presented: to productivity and to foreign demand. The shocks are chosen for two reasons. First, one is a domestic shock and the other is a foreign shock. Second, the two shocks should lead to opposite effects on inflation. The labour augmenting productivity shock is expected to temporarily lower inflation, while the foreign demand shock should produce upward pressure on inflation.

Productivity, $z_{t}$, and foreign demand, $y_{t}^{*}$, are univariate exogenous processes with normally distributed errors and evolve according to

$z_{t}=\rho_{z} z_{t-1}+\varepsilon_{z, t}, \quad$ where $\varepsilon_{z, t} \sim$ i.i.d.N $\left(0 ; \sigma_{z}^{2}\right)$

$y_{t}^{*}=\rho_{y^{*}} y_{t-1}^{*}+\varepsilon_{y^{*}, t}$, where $\varepsilon_{y^{*}, t} \sim$ i.i.d.N $\left(0 ; \sigma_{y^{*}}^{2}\right)$

The autocorrelation coefficient of both processes are assumed to be 0.95 , i.e. $\rho_{y^{*}}=\rho_{z}=0.95$. The innovation variances are given by $\sigma_{z}^{2}=(0.007)^{2}$ and $\sigma_{y^{*}}^{2}=(0.02)^{2}$.

The impulse responses to a positive productivity shock and a positive foreign demand shock are plotted in Figs. 1 and 2. They are in percent deviations from steady state. The equations of the baseline model with all three channels operating are given in Appendix C. ${ }^{16}$ The solid thick line in Figs. 1 and 2 shows the responses in the baseline model. The solid thin line plots the adjustment paths of the economy without the interest rate channel and the light dotted line of the economy without the exchange rate channel. The dark dotted line shows the impulse responses of the economy without the credit channel. All variables eventually return to steady state.

The main results can be summarised as follows. The impulse responses show that all three channels contribute to business cycle dynamics. The credit channel has an important influence on the central bank's response to shocks, while the exchange rate channel magnifies output fluctuations. But the largest effects arise from the interest rate channel. These findings are robust to different specifications of the model. ${ }^{17}$

\subsection{Productivity shock}

A positive shock to labour augmenting productivity (Fig. 1) produces an increase in output and employment in all four models. Investment, imports and consumption are also higher, except in the model with no interest rate channel. The effects are smaller in the no exchange rate channel model. With the exchange rate channel shutdown, the exchange rate no longer appreciates following the positive supply shock, leading to a smaller increase in imports, output and the current account deficit. The exchange rate channel thus magnifies the business cycle fluctuations following the productivity shock.

The positive supply shock is initially accommodated by the monetary authority and the interest rate falls in the baseline model and the model with no exchange rate channel. The central bank eases monetary policy because the positive supply shock produces a negative output gap that puts downward pressure on inflation. The negative output gap arises as actual output increases more slowly

\footnotetext{
16 The log-linearised model is solved with the method of undetermined coefficients. Uhlig's (1999) procedures for MATLAB are used.

17 The results and supporting figures from sensitivity analysis are not presented but are available on request.
}

than flexible price output. Actual output rises more slowly because investment only increases with a lag. The delayed response in investment results because of the credit channel. Entrepreneurs must accumulate net worth to expand production but their capital stock is initially fixed. ${ }^{18}$ Moreover, the positive supply shock increases the demand and price for capital, dampening further the rise in actual output. Eventually, the negative output gap is followed by a small positive gap. Inflation rises and the central bank tightens monetary policy.

In the model with no credit channel, entrepreneurs do not need to accumulate net worth to expand production following the positive productivity shock. As a result, the increase in actual output is instantaneous and larger than in flexible price output. This leads to an immediate tightening in monetary policy as the output gap becomes positive. Turning off the credit channel thus illustrates the importance of the credit channel for the central bank's response. The credit channel leads to a larger decline in interest rates following a positive supply shock because it dampens the magnitude of the output response.

When the interest rate channel is suppressed, the central bank no longer responds to the positive productivity shock and output increases by less. Turning off the monetary response leads to large and persistent deviations from steady state in the inflation and exchange rates with consequent adverse effects on the real economy. Following the positive productivity shock, the real exchange rate depreciates rather than appreciates. This produces a rise in exports (and a decline in the current account deficit). The rise in exports reduces domestic aggregate consumption and investment. Moreover, the depreciation of the exchange rate dampens the rise in output as it raises the cost of imports, which are a production input. The real exchange rate depreciation causes a decline in flexible price output, a positive output gap and a sharp rise in inflation.

Overall, the results show that the interest rate channel has the largest effects of the three channels on the business cycle. That is, the differences between the responses of the baseline model and the no interest rate channel model are substantially larger than the differences between the responses of the baseline and the other two models (no credit or exchange rate channel).

\subsection{Foreign demand shock}

Fig. 2 gives the impulse responses to the foreign demand shock. The foreign demand shock has more similar effects in all four models than the responses to the productivity shock. This reflects the fact that the shock only affects a proportion of output, which is export. But the interest rate channel continues to have the largest impact on the business cycle.

The positive foreign demand shock leads to a rise in exports, output and employment and a decline in investment and consumption. The increase in output produces a positive output gap, inflationary pressures and a tightening in monetary policy, except for the model with no interest rate channel. Higher interest rates are followed by an appreciation of the real exchange rate, apart from in the no exchange rate channel model, and flexible price output increases, apart from in the no interest rate channel model. But the rise in flexible price output is insufficient to meet increased foreign demand, leading to the positive output gap and inflationary pressures.

The real appreciation of the domestic currency leads to an increase in imports and a substitution from domestic factors of production (labour and capital) to foreign factors (imports). However, exports increase by more following the positive foreign demand shock than

\footnotetext{
18 An increase in the price and rental rate of capital, the value of entrepreneurs' capital and net worth raises the return to internal funds. The higher return to internal funds leads entrepreneurs to reduce consumption and accelerates their accumulation of capital and net worth.
} 
imports and the current account deficit falls. The current account deficit declines by more when the interest rate channel is shutdown. This is because the non responsiveness of the interest rate leads to a sharp rise in inflation and a depreciation of the real exchange rate. As in the case of the productivity shock, the benefits of the positive shock are partly offset when the interest rate channel is turned off as the depreciation of the real exchange rate increases the cost of production and lowers output.

The output effects are smaller in the no exchange rate channel model and the current account deficit falls by more than in the baseline model. This is because the real exchange rate no longer appreciates following the tightening in monetary policy, leading to a smaller increase in imports and output (and larger rise in exports) than in the baseline model.

The results also illustrate how the output effects of the positive demand shock are magnified by the credit channel (whereas they were dampened in the case of the positive productivity shock). Output increases by more in the presence of the credit channel because the price of capital and hence the cost of production falls. Without the credit channel the price of capital is unaffected by the foreign demand shock. Output rises by less, requiring a smaller increase in interest rates.

\section{Net worth}

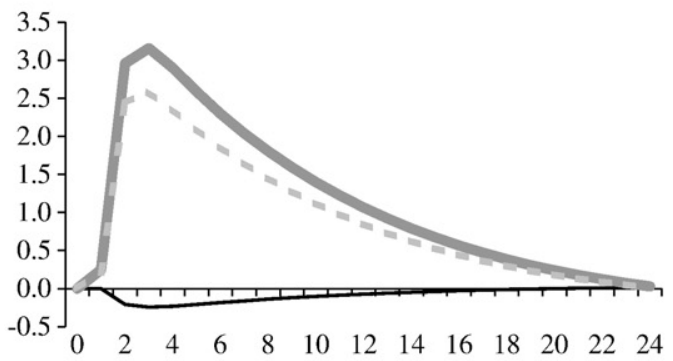

Aggregate consumption

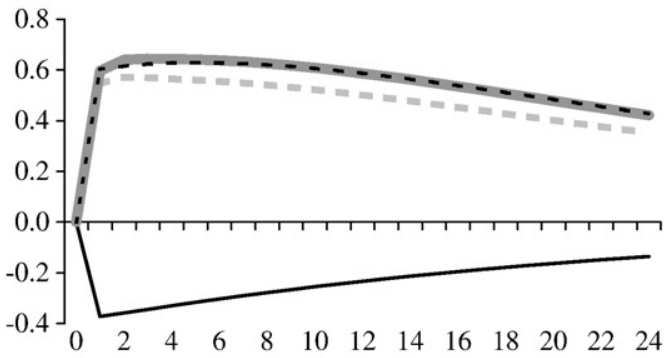

Exports

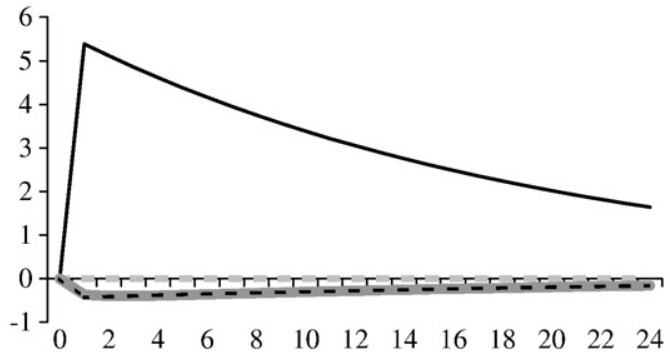

Household labour

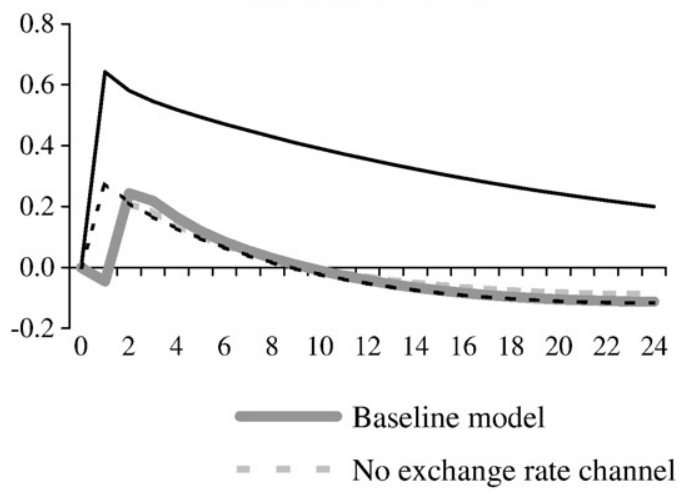

Investment

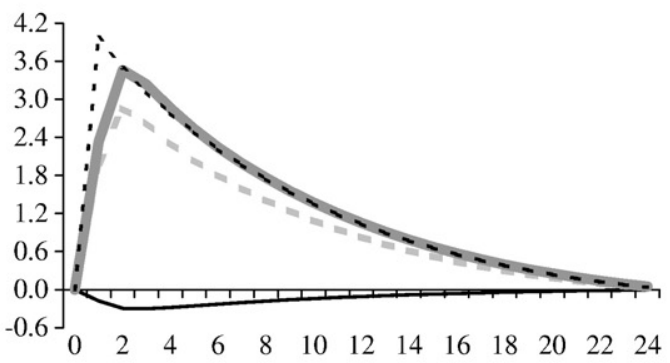

Government consumption

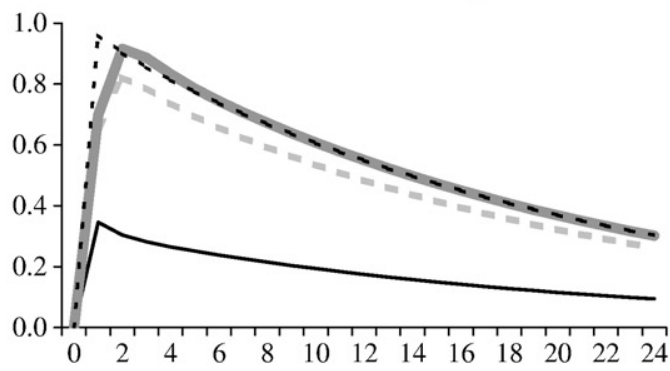

Output

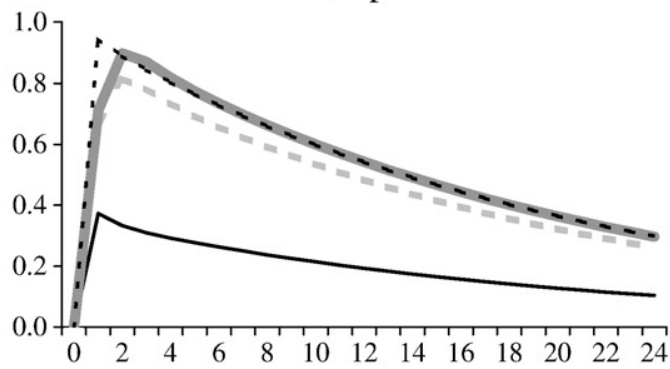

Imports

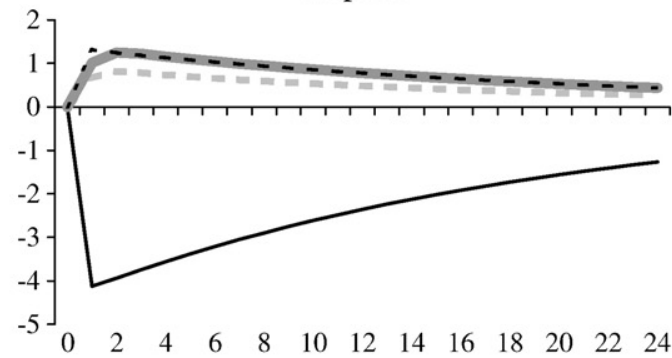

-... . No credit channel

No interest rate channel

Fig. 1. Impulse responses to a productivity shock (in percent deviations from steady state). 


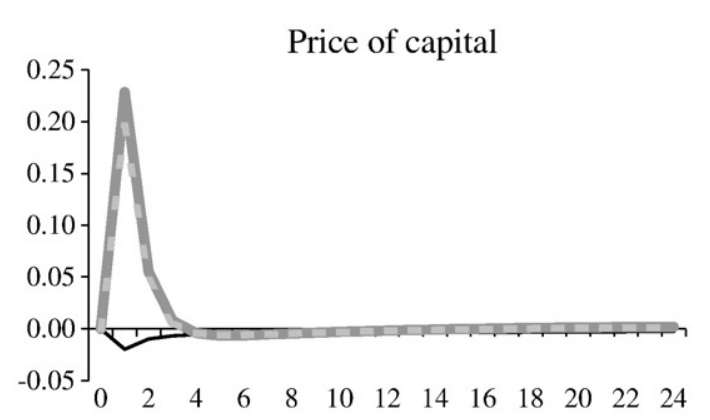

Current account deficit

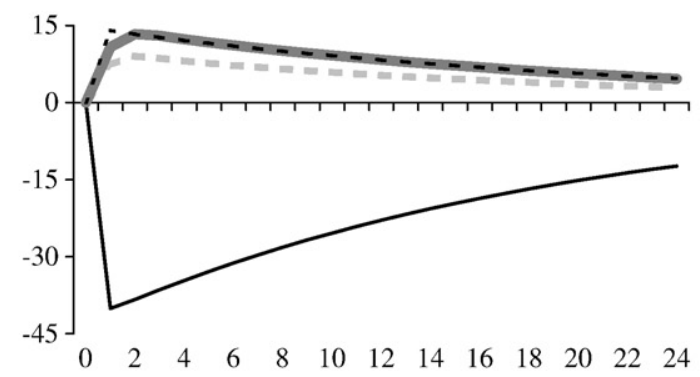

Inflation

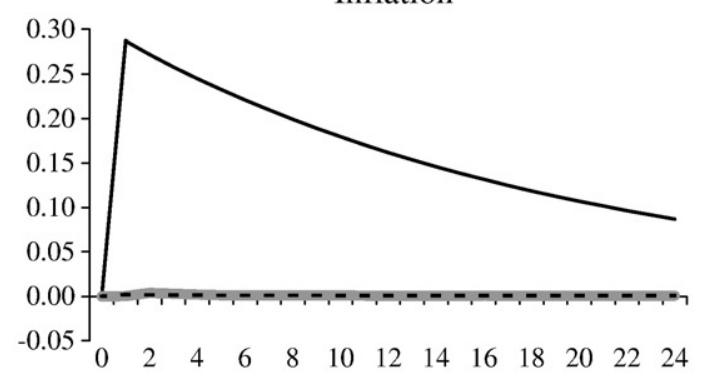

Flexible price output

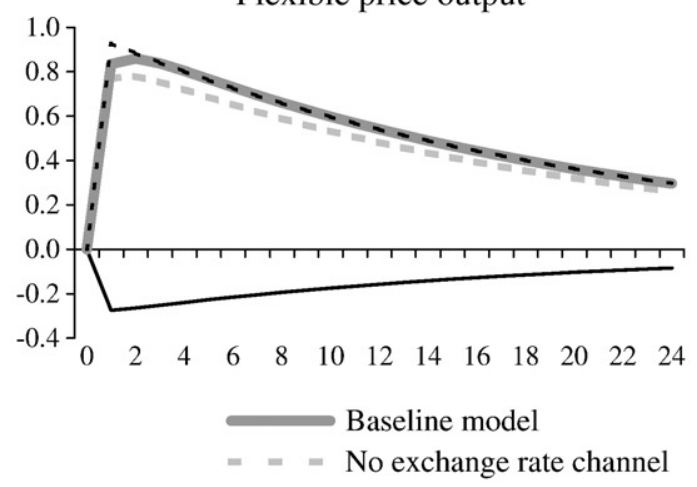

Rental rate of capital

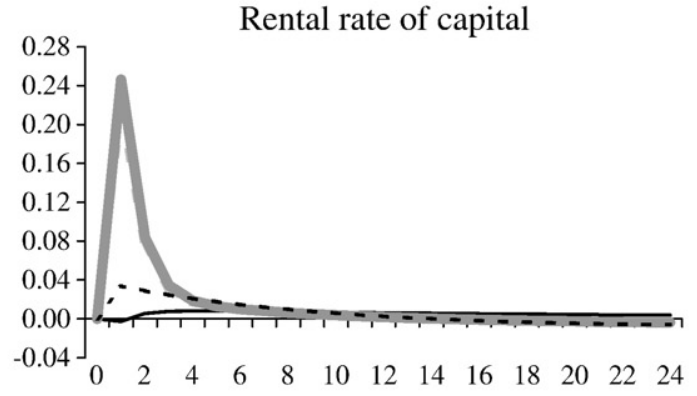

Interest rate

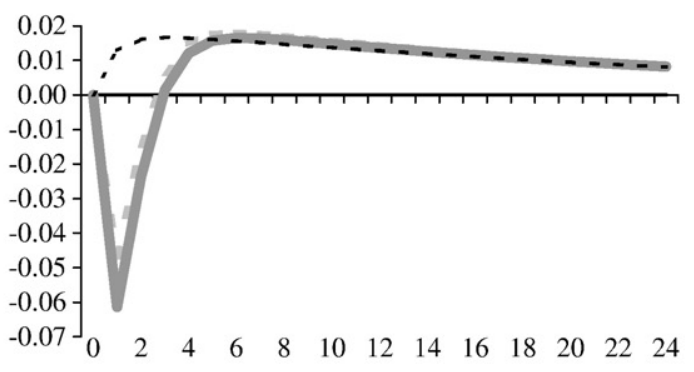

Real exchange rate
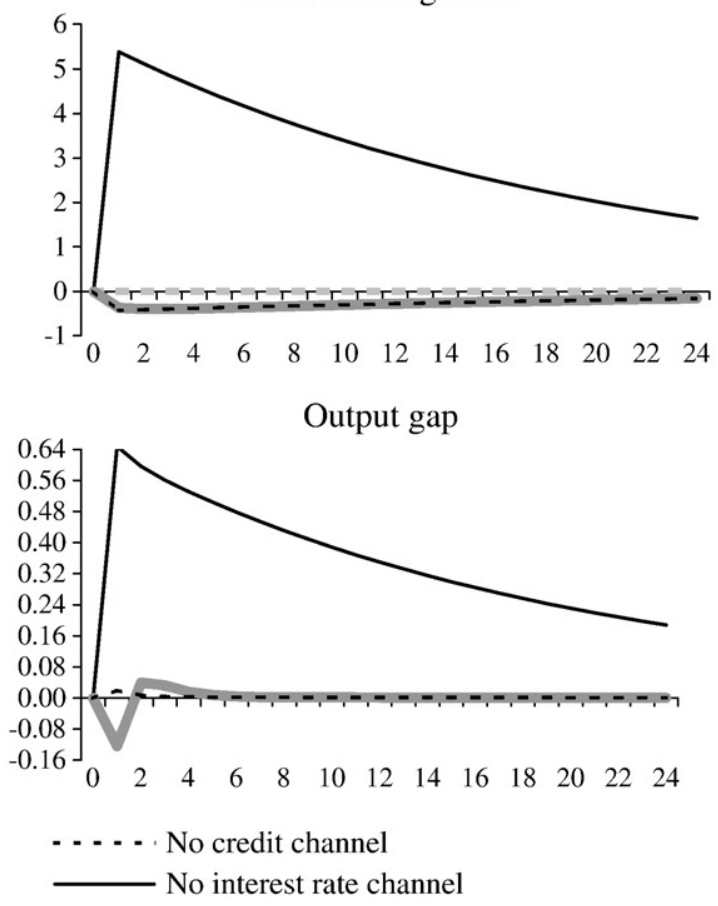

Fig. 1 (continued).

\section{Concluding remarks}

This paper developed a dynamic general equilibrium model to assess the importance of the credit channel relative to the interest and exchange rate channels in transmitting shocks to the economy. It was motivated by increasing theoretical and empirical evidence that credit market conditions affect the propagation of cyclical fluctuations in the economy. The model was calibrated for New Zealand, a small, open and deregulated economy. The relative contribution of each channel was determined by comparing the impulse responses when the relevant channel is suppressed with the impulse responses when all three channels are operating.

The analysis showed that all three channels affect business cycle dynamics and these results are robust to different specifications of the model. The credit channel has an important influence on the central bank's response to shocks, while the exchange rate channel magnifies output fluctuations. But overall, the interest rate channel has the largest effects in the transmission of shocks to the economy. The results suggest that it is substantially more important than the credit channel. 


\section{Acknowledgements}

I would like to thank an anonymous referee, Louise Allsopp, Bob Buckle, Stephen Burnell, Edda Claus, Alfred Guender, Arthur Grimes, Viv Hall, Timo Henckel, Kunhong Kim, Dimitri Margaritis, Weshah Razzak and Graeme Wells for useful comments. All errors, omissions and views in this paper are my own responsibility.

\section{Appendix A. Parameterisation of the model}

Households' discount rate, $\beta$, equals 0.9902 and leads to an annual steady state, real domestic interest rate of 4 percent. The coefficient on

Net worth

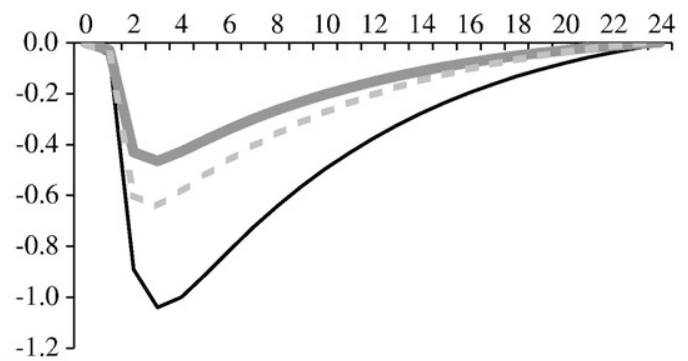

Aggregate consumption

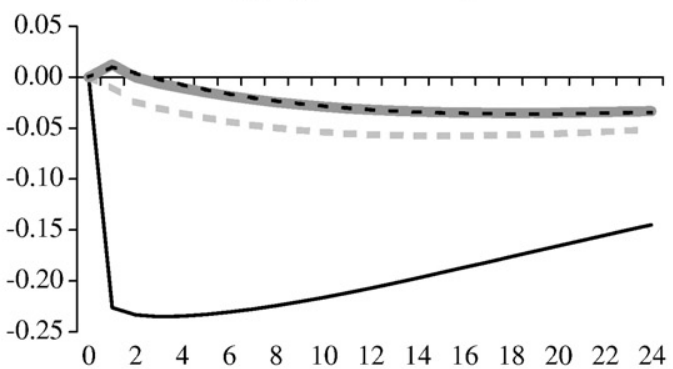

Exports

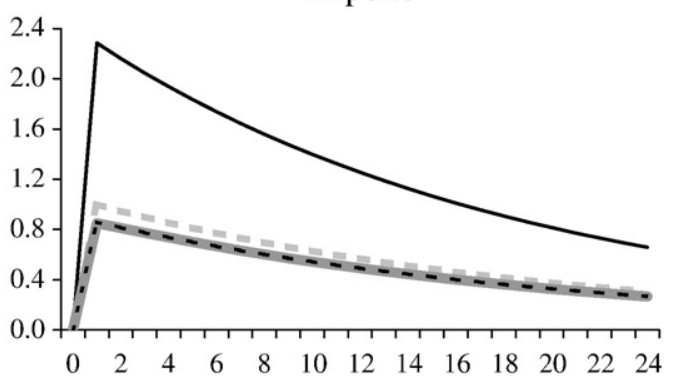

Household labour

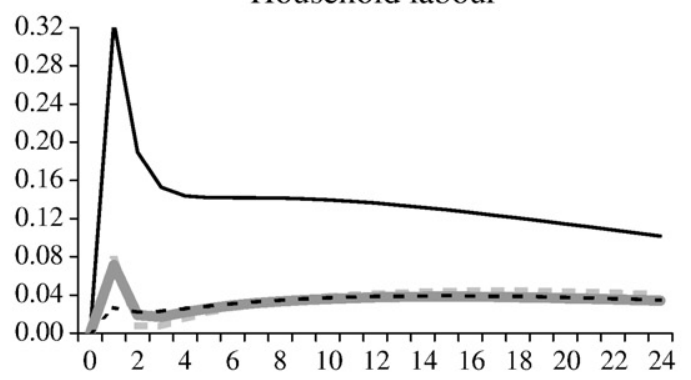

leisure, $\gamma$, in households' utility function is chosen so that their work effort accounts for a third of their time endowment in steady state. The ratio of entrepreneurs to households, $\eta$, is arbitrarily set to 0.1 .

Entrepreneurs' extra discount factor, $\vartheta$, is 0.947 and the monitoring cost, $\alpha$, is 0.25 . The bankruptcy rate, $\Phi(\bar{\varpi})$, equals 0.974 percent per quarter and the standard deviation of the idiosyncratic technology, $\sigma$, is 0.207. These assumptions are the same as in Carlstrom and Fuerst (1997).

Productivity, $\bar{Z}$, is normalised to 1 in steady state. The elasticity of substitution between labour, capital and commodity inputs, $1 /(1-\nu)$, is set to 0.85 in line with estimates for New Zealand by Hall and Scobie

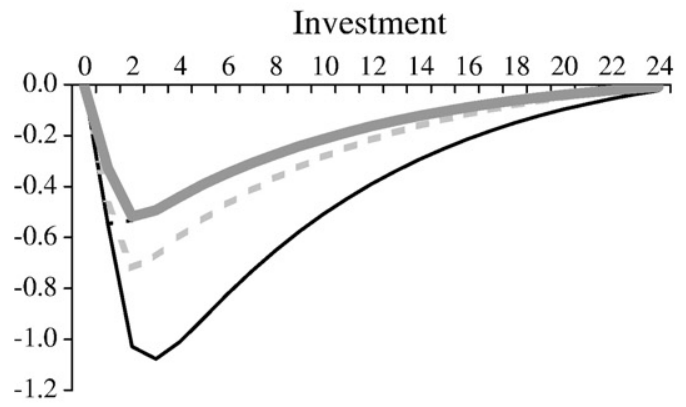

Government consumption

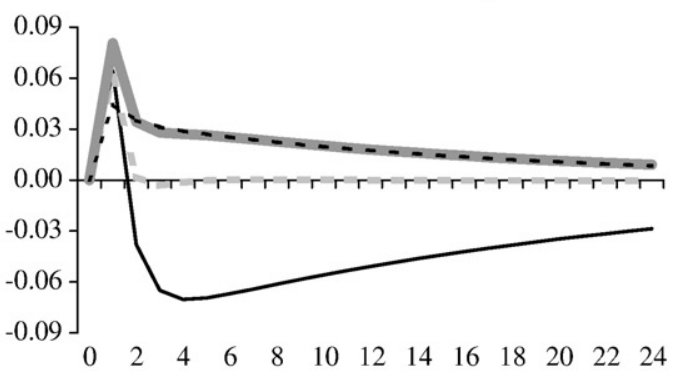

Output

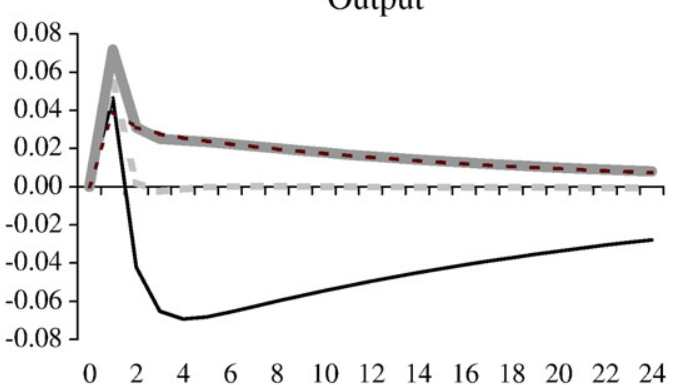

Imports

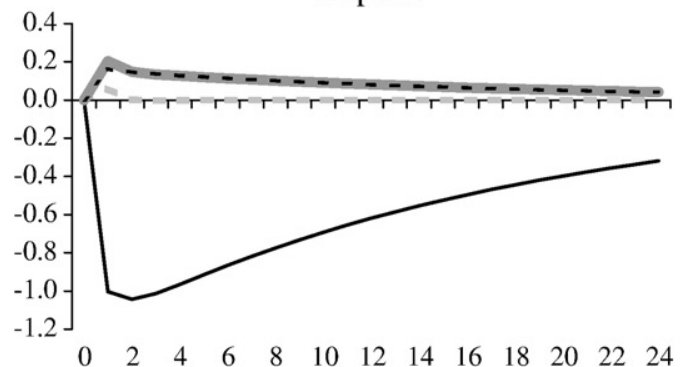

.... . No credit channel No interest rate channel

Fig. 2. Impulse responses to a foreign demand shock (in percent deviations from steady state). 
Price of capital

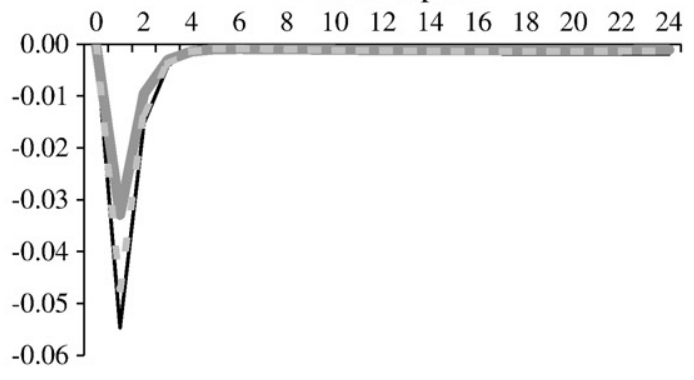

Current account deficit

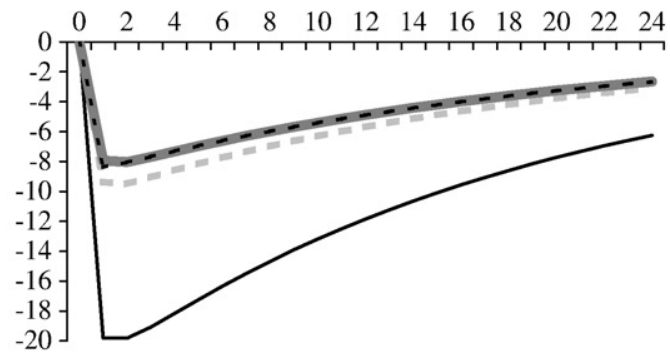

Inflation

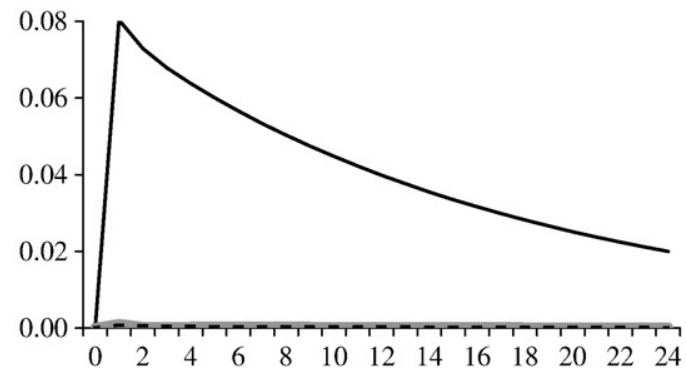

Flexible price output

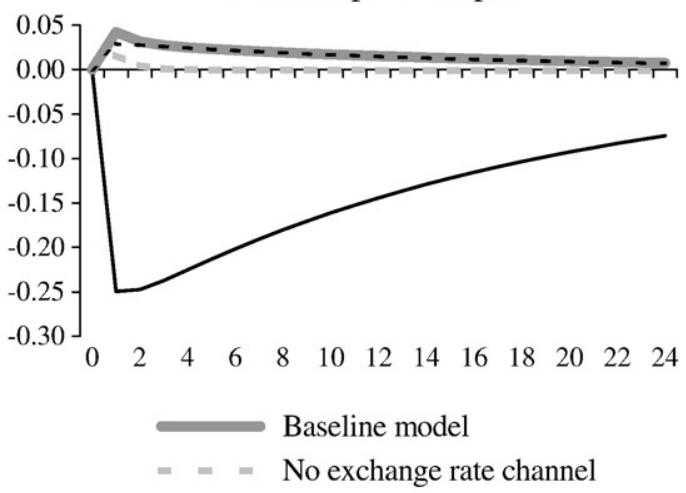

Rental rate of capital

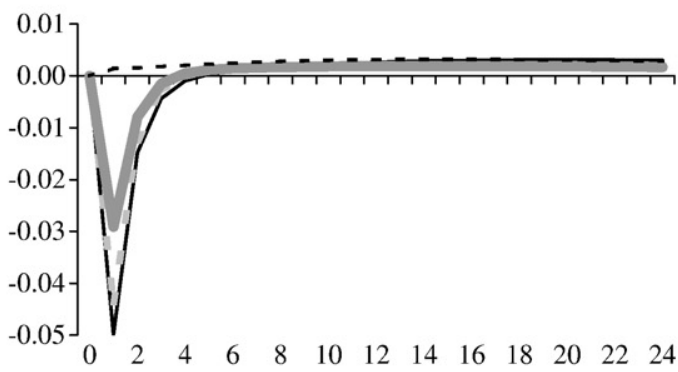

Interest rate

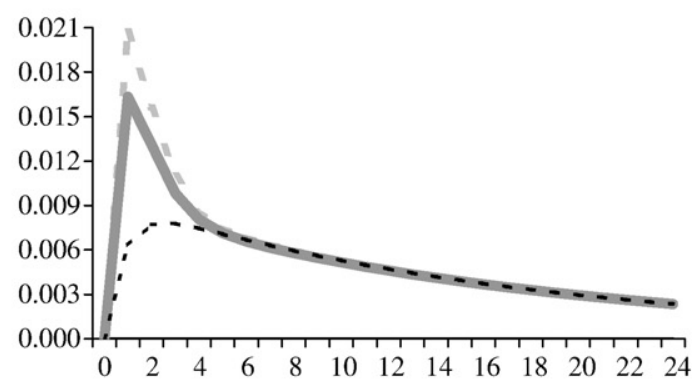

Real exchange rate

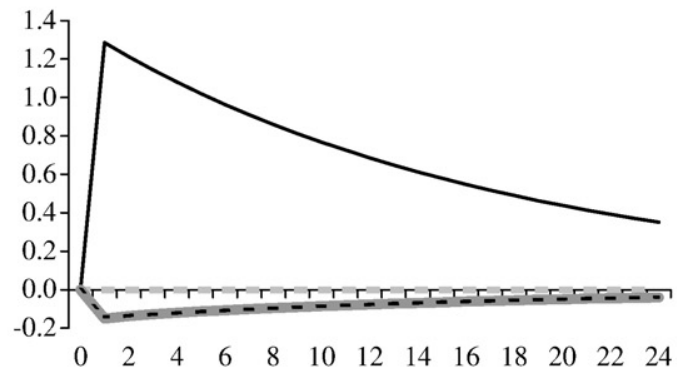

Output gap

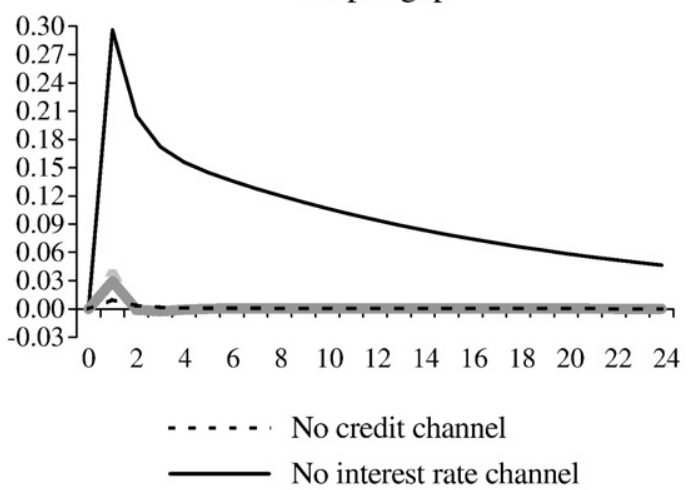

Fig. 2 (continued).

(2005). The coefficients on household labour, $\eta_{l}$, capital, $\eta_{k}$, and commodity inputs, $\eta_{i m}$, in firms' production function are $0.5399,0.36$ and 0.1 respectively. They are broadly in line with New Zealand inputoutput data and yield a steady state ratio of imports to output of about 12 percent, the same as in McCallum and Nelson (1999). The capital depreciation rate, $\delta$, equals 8.5 percent per annum, the same as in the Reserve Bank's model and firms' mark-up in steady state is 20 percent $(\theta /(\theta-1)=1.2)$, i.e. $\theta=6$, the same as in McCallum and Nelson (1999).

The annual domestic steady state inflation rate, $\Pi^{T}$, of 2 percent is equal to the mid-point of the Reserve Bank of New Zealand's 1 to 3 percent target band for consumer price inflation. The tax rate, $\tau$, equals 17 percent in line with the income tax assumption in the Reserve Bank's model. The steady state foreign inflation rate, $\bar{\Pi}$, and nominal bond rate, $\bar{I}$, are assumed to be the same as for the domestic economy and the steady state real exchange rate, $\bar{Q}$, is normalised to 1. The price and foreign demand elasticities of exports, $\kappa$ and $\varsigma$, are equal to unity, as in McCallum and Nelson (2000). Foreign demand is chosen to yield a steady state ratio of exports to output of 11 percent, the same as in McCallum and Nelson (1999), leading to a current account deficit of around -1 percent of steady state output. 


\section{Appendix B. Steady state}

The steady state of the baseline model can be solved for as follows, where $\bar{K}, \bar{K}^{e}, \overline{N W}, \overline{I N}, \bar{C}^{h}, \bar{C}^{e}, \bar{C}, \bar{G}, \overline{E X}, \bar{Y}, \bar{L}^{h}$ and $\overline{I M}$ denote steady state averages:

$\bar{L}^{h}=\frac{0.3(1-\eta)}{\eta}$

$\Phi(\bar{\varpi})=0.00974$

$\bar{\Psi}=\frac{1}{1-\alpha \Phi(\bar{\varpi})+\frac{\alpha \phi(\bar{\varpi}) f(\bar{\varpi})}{f^{\prime}(\bar{\varpi})}}$

$\overline{I R}=\frac{f(\bar{\varpi}) \bar{\Psi}}{1-g(\bar{\varpi}) \bar{\Psi}}-1$

$\bar{R}=\frac{\bar{\Psi}}{1-\tau}$

Using firm's first-order conditions

$\bar{K}=\bar{Y}\left(\frac{((1+(1-\tau) \bar{R})-(1-\delta) \bar{\Psi}) \frac{\theta}{\theta-1}}{(1-\tau) \eta_{k}}\right)^{\frac{1}{\nu-1}}$

$\bar{I} M=\bar{Y}\left(\frac{\frac{\theta}{\theta-1} \bar{Q}}{\eta_{\text {im }}}\right)^{\frac{1}{\nu-1}}$

and the production function

$\bar{Y}^{v}=\eta_{l}\left(\bar{Z} \bar{L}^{h}\right)^{v}+\eta_{k} \bar{K}^{v}+\eta_{i m} \overline{I M}^{v}+\left(1-\eta_{l}-\eta_{k}-\eta_{i m}\right)$

$\bar{Y}$ can be derived as

$\bar{Y}=\left(\frac{\eta_{l}\left(\bar{Z} \bar{L}^{h}\right)^{v}+\left(1-\eta_{l}-\eta_{k}-\eta_{\text {im }}\right)}{1-\eta_{k}\left(\frac{((1+(1-\tau) \bar{R})-(1-\delta) \bar{\Psi}) \frac{\theta}{\theta-1}}{(1-\tau) \eta_{k}}\right)^{\frac{\nu}{\nu-1}}-\eta_{\text {im }}\left(\frac{\frac{\theta}{\theta-1} \bar{Q}}{\eta_{\text {im }}}\right)^{\frac{\nu}{\nu-1}}}\right)^{\frac{1}{\nu}}$

$\overline{I N}=\frac{\delta \bar{K}}{1-\alpha \Phi(\bar{\varpi})}$

$N \overline{N W}=\overline{I N}(1-g(\bar{\varpi}) \bar{\Psi})$

$\bar{K}^{e}=\frac{\overline{N W}-\frac{(1-\tau)\left(1-\eta_{l}-\eta_{k}-\eta_{i m}\right) \bar{Y}^{1-v}}{\frac{\theta}{\theta-1}}}{(1+(1-\tau) \bar{R})}$

$\bar{C}^{e}=N \bar{W}(1+\overline{I R})-\bar{\Psi} \bar{K}^{e}$

$\overline{E X}=0.11 \cdot \bar{Y}$

$\bar{G}=\tau\left(\frac{\bar{Y}-\eta_{i m} \bar{Y}^{1-v} \overline{I M}^{\nu}}{\frac{\theta}{\theta-1}}\right)$

$\bar{C}^{h}=\frac{\eta\left(\bar{Y}-\bar{C}^{e}-\bar{G}-\overline{E X}-I \overline{I N}\right)}{(1-\eta)}$

$\bar{C}=\frac{(1-\eta) \bar{C}^{h}}{\eta}+\bar{C}^{e}$

$\bar{C} A=\overline{E X}-\bar{Q} \overline{I M}$

\section{Appendix C. Dynamic model}

The baseline dynamic model is described by Eqs. (30), (32) and (33) and the following equations:

$$
\begin{aligned}
& (1-v) y_{t}-(1-v) l_{t}^{h}-c_{t}^{h}+v z_{t}+\frac{1}{\theta}\left(y_{t}-\tilde{y}_{t}\right)-i_{t}=0 \\
& \bar{K} k_{t}-(1-\delta) \bar{K} k_{t-1}-\overline{I N}(1-\alpha \Phi(\bar{\varpi})) i n_{t}+\overline{I N} \alpha \phi(\bar{\varpi}) \bar{\varpi} \varpi_{t}=0 \\
& \frac{(1-\tau)(1-v) \eta_{k}\left(\frac{\bar{Y}}{\bar{K}}\right)^{1-v}}{\frac{\theta}{\theta-1}} y_{t}+(1-\delta) \bar{\Psi} \psi_{t}-\frac{(1-\tau)(1-v) \eta_{k}\left(\frac{\bar{Y}}{\bar{K}}\right)^{1-v}}{\frac{\theta}{\theta-1}} k_{t-1} \\
& +\frac{(1-\tau) \eta_{k}\left(\frac{\bar{Y}}{\bar{K}}\right)^{1-v}}{\frac{\theta^{2}}{\theta-1}}\left(y_{t}-\tilde{y}_{t}\right)-(1+(1-\tau) \bar{R}) r_{t}=0 \\
& \frac{(1-\eta) \bar{C}^{h}}{\eta} c_{t}^{h}+\bar{C}^{e} c_{t}^{e}+\bar{G} g_{t}+\overline{E X} e x_{t}+\overline{I N} i n_{t}-\bar{Y} y_{t}=0 \\
& \frac{1}{\bar{\Psi}} \psi_{t}+\frac{f(\bar{\varpi})}{f^{\prime}(\bar{\varpi})}\left(\frac{\phi^{\prime}(\bar{\varpi})}{\phi(\bar{\varpi})}-\frac{f^{\prime \prime}(\bar{\varpi})}{f^{\prime}(\bar{\varpi})}\right) \alpha \phi(\bar{\varpi}) \bar{\varpi} \varpi_{t}=0 \\
& i r_{t}+n w_{t}-\psi_{t}-\frac{f^{\prime}(\bar{\varpi}) \bar{\varpi}}{f(\bar{\varpi})} \varpi_{t}-i n_{t}=0 \\
& \frac{(1-\tau)(1-v)\left(1-\eta_{l}-\eta_{k}-\eta_{i m}\right) \bar{Y}^{1-v}}{\frac{\theta}{\theta-1}} y_{t} \\
& +\frac{(1-\tau)\left(1-\eta_{l}-\eta_{k}-\eta_{i m}\right) \bar{Y}^{1-v}}{\frac{\theta^{2}}{\theta-1}}\left(y_{t}-\tilde{y}_{t}\right) \\
& +(1+(1-\tau) \bar{R}) \bar{K}^{e} k_{t-1}^{e}+(1+(1-\tau) \bar{R}) \bar{K}^{e} r_{t}-N W n w_{t}=0
\end{aligned}
$$

$N \bar{N}(1+\overline{I R}) n w_{t}+N \bar{W}(1+\overline{I R}) i r_{t}-\bar{C}^{e} c_{t}^{e}-\bar{\Psi} \bar{K}^{e} \psi_{t}-\bar{\Psi} \bar{K}^{e} k_{t}^{e}=0$

$$
\begin{aligned}
& \frac{1}{1-g(\bar{\varpi}) \bar{\Psi}^{\prime}} \psi_{t}+\left(\frac{g^{\prime}(\bar{\varpi}) \bar{\Psi}}{1-g(\bar{\varpi}) \bar{\Psi}}+\frac{f^{\prime}(\bar{\varpi})}{f(\bar{\varpi})}\right) \bar{\varpi} \varpi_{t}-i r_{t}=0 \\
& \eta_{l}\left(\frac{\bar{Z} \bar{L}^{h}}{\bar{Y}}\right)^{v} z_{t}+\eta_{l}\left(\frac{\bar{Z} \bar{L}^{h}}{\bar{Y}}\right)^{v} l_{t}^{h}+\eta_{k}\left(\frac{\bar{K}}{\bar{Y}}\right)^{v} k_{t-1}+\eta_{i m}\left(\frac{\overline{I M}}{\bar{Y}}\right)^{v} i m_{t}-y_{t}=0 \\
& \frac{\tau\left(\bar{Y}-\eta_{i m}(1-v) \bar{Y}^{1-v} \overline{I M}^{v}\right)}{\frac{\theta}{\theta-1}} y_{t}+\frac{\tau\left(\bar{Y}-\eta_{i m} \bar{Y}^{1-v} \overline{I M}{ }^{v}\right)}{\theta^{2}}\left(y_{t}-\tilde{y}_{t}\right) \\
& -\frac{\tau \eta_{i m} v \bar{Y}^{1-v} \overline{I M}^{v}}{\theta} i m_{t}-\bar{G} g_{t}=0 \\
& \frac{\theta-1}{\theta-1}
\end{aligned}
$$

$e x_{t}-\kappa q_{t}-\varsigma y_{t}^{*}=0$

$q_{t}-(1-v) y_{t}-\frac{1}{\theta}\left(y_{t}-\tilde{y}_{t}\right)+(1-v) i m_{t}=0$

$\bar{C} c_{t}-\frac{(1-\eta)}{\eta} \bar{C}^{h} c_{t}^{h}-\bar{C}^{e} c_{t}^{e}=0$

$\overline{C A C a} a_{t}-\overline{E X} e x_{t}+\bar{Q} q_{t}+\overline{I M i m}{ }_{t}=0$

$c_{t}^{h}-\psi_{t}+E_{t}\left[r_{t+1}\right]-E_{t}\left[c_{t+1}^{h}\right]-E_{t}\left[i_{t+1}\right]=0$

$E_{t}\left[r_{t+1}\right]+E_{t}\left[i r_{t+1}\right]-\psi_{t}=0$

$E_{t}\left[q_{t+1}\right]-E_{t}\left[q_{t}\right]+E_{t}\left[i_{t+1}^{*}\right]-E_{t}\left[\pi_{t+1}^{*}\right]-E_{t}\left[i_{t+1}\right]+E_{t}\left[\pi_{t+1}\right]=0$ 


\section{References}

Bernanke, B.S., Gertler, M., 1989. Agency costs, net worth, and business fluctuations. The American Economic Review 79, 14-31.

Bernanke, B.S., Gertler, M., Gilchrist, S., 1999. The Financial Accelerator in a Quantitative Business Cycle Framework. In: Taylor, J.B., Woodford, M. (Eds.), Handbook of macroeconomics, vol. 1C. North-Holland, Amsterdam, pp. 1341-1393.

Braun, M., Larrain, B., 2005. Finance and the business cycle: International interindustry evidence. The Journal of Finance 60, 1097-1128.

Calvo, G.A., 1983. Staggered prices in a utility-maximizing framework. Journal of Monetary Economics 12, 383-398.

Carlstrom, C.T., Fuerst, T.S., 1997. Agency costs, net worth, and business fluctuations: a computable general equilibrium analysis. The American Economic Review 87, 893-910.

Dungey, M., Pagan, A., 2000. A structural VAR model of the Australian economy. The Economic Record 76, 321-342.

Fisher, I., 1933. The debt-deflation theory of great depressions. Econometrica 1 , 337-357.

Gertler, M., Gilchrist, S., 1994. Monetary policy, business cycles, and the behavior of small manufacturing firms. Quarterly Journal of Economics 109, 309-340.

Hall, J., Scobie, G., 2005. Capital Shallowness: A Problem for New Zealand? New Zealand Treasury Working Paper. 05/05.

Huang, A., Margaritis, D., Mayes, D., 2001. Monetary policy rules in practice: evidence from New Zealand. Multinational Finance Journal 5, 175-200.

Ludvigson, S., Steindel, C., Lettau, M., 2002. Monetary policy transmission through the consumption-wealth channel. Federal Reserve Bank of New York Economic Policy Review 8, 117-133.
McCallum, B.T., Nelson, E., 1999. Nominal income targeting in an open-economy optimizing model. Journal of Monetary Economics 43, 553-578.

McCallum, B.T., Nelson, E., 2000. Monetary policy for an open economy: an alternative framework with optimizing agents and sticky prices. Oxford Review of Economic Policy 16, 74-91.

Mody, A., Sarno, L., Taylor, M.P., 2007. A cross-country financial accelerator: evidence from North America and Europe. Journal of International Money and Finance 26, 149-165.

Ramey, V., 1993. How important is the credit channel in the transmission of monetary policy? Carnegie-Rochester Conference Series on Public Policy 39, 1-45.

Tang, H.C., 2006. The relative importance of monetary policy transmission channels in Malaysia. Centre For Applied Macroeconomic Analysis Working Paper Series. 23/ 2006.

Taylor, J.B., 1993. Discretion versus policy rules in practice. Carnegie-Rochester Series on Public Policy 39, 195-214.

Townsend, R.M., 1979. Optimal contracts and competitive markets with costly state verification. Journal of Economic Theory 21, 265-293.

Uhlig, H., 1999. A Toolkit for Analysing Nonlinear Dynamic Stochastic Models Easily. In: Marimon, R., Scott, A. (Eds.), Computational methods for the study of dynamic economies. Oxford University Press, Oxford, pp. 30-61.

Wicksell, K., 1906. Lectures on political economy. Reprints of economic classics, 1967, vol.2. Augustus M. Kelly, New York, pp. 127-208.

Williamson, S.D., 1986. Costly monitoring, financial intermediation, and equilibrium credit rationing. Journal of Monetary Economics 18, 159-179. 